\title{
Športni turizem
}

\author{
Miha Lesjak \\ UP Fakulteta za turistične študije - Turistica \\ miha.lesjak@fts.upr.si
}

\section{Uvod}

Potovalne navade posameznika so se skozi stoletja razvoja družbe in turizma spreminjale. Zanimanje za šport in druge s športom povezane aktivnosti (športne prireditve, športne aktivnosti v naravi in s športom povezna zgodovina oz. športna nostalgija) so po podatkih Svetovne turistične organizacije (World Tourism Organization, 2002) zadosten razlog, da je šport postal pomemben potovalni motiv na nivoju globalnega turizma.

Športni turizem večinsko sestavljata dve znanstveni področji. Gre za področji športa in turizma, ki pa se povezujeta še s številnimi drugimi znanstvenimi disciplinami, kot so medicina, psihologija, sociologija, ekonomija in druge. Šport in turizem imata številne skupne cilje, ki jih zaznamo v razumevanju drugih kultur in življenjskih slogov, prispevanju k spodbujanju in utrjevanju miru med narodi ter krepitvi tesnejših odnosov med ljudmi različnih kultur. Razcvet športa in turizma lahko v veliki meri pripišemo spremembam življenjskih navad in dostopnosti informacij, ki so na voljo ljudem. Če je nekdaj športni turizem predstavljal dejavnost za elite, je danes zaradi svoje dostopnosti na voljo številnim uporabnikom. $V$ tem poglavju mono- 
grafije Tematski turizem bomo več prostora namenili povezovanju športa in turizma ter opredelili različne vrste športnega turizma, na kratko predstavili potenciale športnega turizma v Sloveniji ter v zaključku poglavja nekaj besed namenili še trendom na področju globalnega športnega turizma.

\section{Šport in turizem}

Šport je sestavni del družbenega dogajanja in je zgodovinsko gledano že v antičnem času (organizacija olimpijskih iger) vplival na potovanja ljudi z motivom športa. Izvorno sporočilo besede »šport« je "preusmerjanje pozornosti od nenehnih pritiskov in težav življenja posameznika« (Edwards, 1973 v Hudson, 2003). Šport je danes seveda več kot le gibanje človeka, zato ga je težko natančno definirati. Šport ljudem predstavlja predvsem druženje in sprostitev, hkrati pa je lahko zaradi svoje popularnosti tudi dober posel in vir zaslužka za turistične destinacije, športne organizacije in posameznike, ki oblikujejo športnoturistične produkte.

Coakley (2008) šport opredeli kot institucionalizirano, konkurenčno aktivnost, ki vključuje fizične napore ali uporabo dokaj zahtevnih fizičnih znanj, kjer so udeleženci motivirani z zunanjimi in notranjimi nagradami. Definicija je sestavljena iz štirih delov (Coakley, 2004:

- šport je fizična aktivnost;

- šport je tekmovalna dejavnost (profesionalne in rekreativne narave);

- šport ima določena pravila;

- šport je motiv za zunanje (materialne nagrade) in notranje (izziv) nagrajevanje.

$\mathrm{V} »$ Resoluciji o nacionalnem programu športa v Republiki Sloveniji za obdobje 2014-2023« (2014) je šport definiran na podlagi dokumenta Sveta Evrope. Ta pojem športa opredeli kot »s strani športne stroke dogovorno opredeljene oblike gibalne dejavnosti, ki so z neorganiziranim ali organiziranim ukvarjanjem usmerjene k izražanju ali zboljševanju telesne pripravljenosti, k duševnemu blagostanju in k oblikovanju družbenih odnosov oziroma doseganju rezultatov na različnih ravneh tekmovanj«.

Šport tako tekmovalne kot tudi rekreativne narave lahko zaradi popularnosti in privlačnosti opredelimo kot velik družbeni fenomen. Že od nekdaj je šport pomembna dejavnost družbe, ki izra- 
ža njeno dinamiko in kulturo ter bogati kakovost posameznikovega življenja (»Resolucija o Nacionalnem programu športa v Republiki Sloveniji 2014-2023«, 2014). Šport je tudi dejavnost, s katero posamezniki oblikujejo in vzdržujejo standard družbenega sloja. Posledično šport zaradi odrekanja časa, namenjenega počitku in drugim aktivnostim, predstavlja velik del posameznikovih interesov in dejavnosti ter je pomembno gonilo aktivne in zdrave družbe (Coakley, 2008).

Športna dejavnost pa ne predstavlja samo fizične aktivnosti in pozitivnega vpliva na zdravje posameznika, ampak igra tudi pomembno vlogo za lokalno, nacionalno in globalno gospodarstvo. V Evropski uniji športna industrija in z njo povezane aktivnosti predstavljajo gonilo razvoja napredka evropske družbe. Podatki za leto 2018 kažejo, da je v s športom povezanih panogah zaposlenih 5,67 milijona oseb, kar predstavlja 2,72\% vseh zaposlenih v Evropski uniji (Eurostat, 2018). V svoji široki opredelitvi je športni sektor motor rasti evropskega gospodarstva, ki ustvarja dodano vrednost in odpira nova delovna mesta v predelovalnem in storitvenem sektorju, hkrati pa spodbuja razvoj in inovativnost. Poleg prispevka gospodarstvu po nekaterih podatkih s športom povezana tekmovanja letno dodatho ustvarijo preko 15 milijonov potovanj turistov z glavnim motivom obiska športnih prireditev. Pričakovana stopnja rasti tržne niše obiska športnih prireditev znaša $6 \%$ letno v naslednjih nekaj letih. Posredni učinek organizacije športnih prireditev v številnih turističnih destinacijah predstavlja razvoj športno-rekreativne infrastrukture in športnoturističnih proizvodov ter posledično vpliva na ustvarjanje večjega turističnega prometa (Eurostat, 2018).

Šport in turizem sta gonilni sili za promocijo in trajnostni gospodarski razvoj turističnih destinacij. Davies in Williment (2008, str. 222) celo trdita, da je šport najhitreje rastoč segment turističnega sektorja. Za ta segment so izjemno pomembna organizacija velikih športnih prireditev (olimpijske igre, svetovna in evropska prvenstva v ekipnih športih). Organizirani globalni športni spektakli "pritegnejo velike množice ljudi, oblikujejo svetovne turistične vzorce ter ustvarjajo trajno zapuščino državi« (Fourie in Santana-Gallego, 2011, str. 1365, v Lesjak, 2018). Velika športna tekmovanja prav tako oblikujejo turistično ponudbo destinacije ter s tem ključno vplivajo na turistični promet (Hinch in Higham, 2001).

Šport in turizem imata poleg gospodarskega pomena tudi pomembne družbene vplive in interese. Te zaznavamo v večjem razu- 


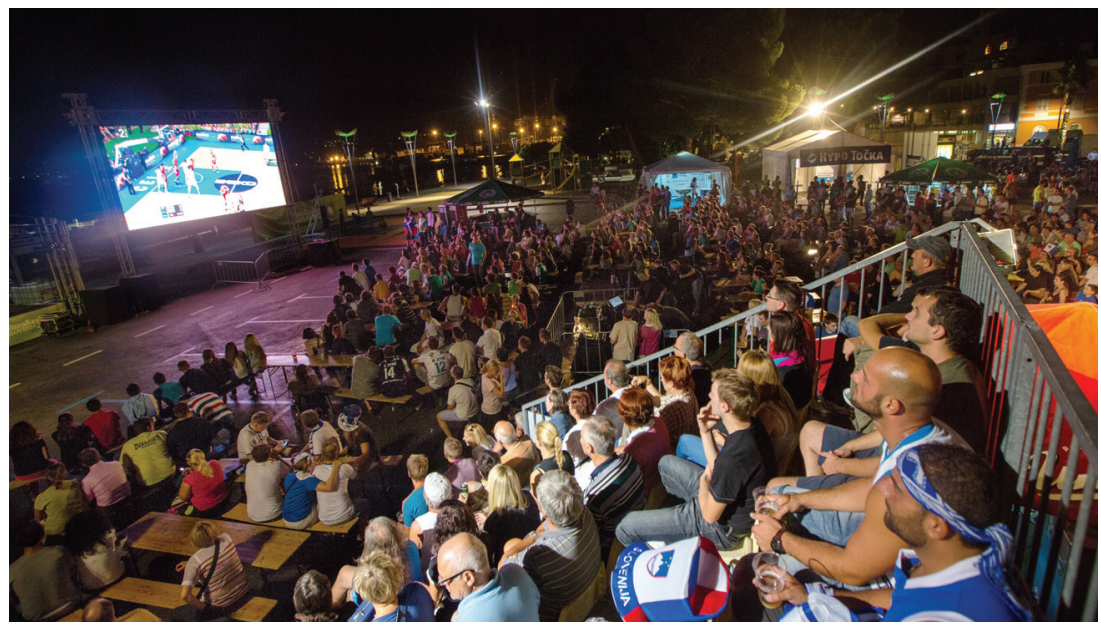

Slika 9.1 Športni turisti velikih športnih prireditev (foto Sportida Photo Agency)

mevanju različnih kultur, življenjskih slogov, tradicij, v spodbujanju miru in dobrih odnosov med narodi. Tako šport kot tudi turizem motivirata in navdihujeta mladino ter ustvarjata zabavo in vplivata na dobro voljo ogromnih množic ljudi (World Tourism Organization, 2002).

Vključevanja športa $\mathrm{v}$ turistično ponudbo je danes stalnica $\mathrm{v}$ turističnem sektorju. Turizem in potovanja pa so temeljno povezana s številnimi oblikami športa (Hinch in Higham, 2001). Šport je, kot ugotavljata Bartoluci in N. Čavlek (2007), pomemben dejavnik razvoja sodobnega turizma in ključen generator dodatnih ekonomskih vrednosti v turizmu.

Pospešen razvoj športnega in turističnega sektorja kot globalnih družbenih pojavov daje obema veliko moč v globalnem gospodarstvu (Hinch in Higham, 2004). Želja ljudi po potovanju z namenom aktivnega preživljanja prostega časa in sodelovanja $\mathrm{v}$ športu postaja stalnica turistične ponudbe. Težnja turistov po iskanju aktivnih počitnic turističnim destinacijam narekuje razvoj novih oblik športnoturistične ponudbe. Že stoletja je tako šport glavni motiv turistov za številna potovanja. Ni torej presenečenje, da je ena izmed pomembnih oblik turizma tudi športni turizem. Danes je povpraševanje po športnem turizmu predvsem posledica večje športne aktivnosti prebivalstva, promocije po bolj zdravem življenjskem slogu, vključevanja v športne aktivnosti starejših (aktivno staranje), pove- 


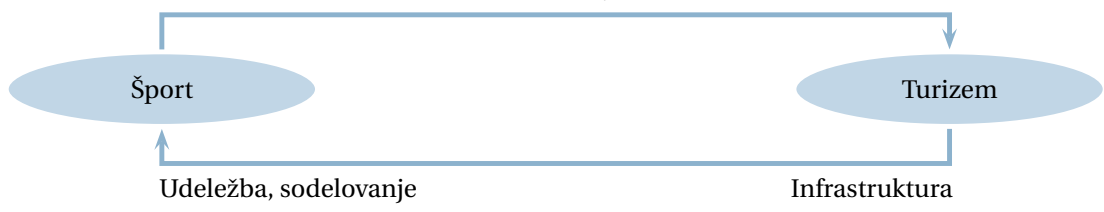

Slika 9.2 Osnovni model športnega turizma (prirejeno po Standeven in De Knop, 1999, str. 5, v Slak Valek, 2008, str. 46)

čanega vključevanja žensk v športne aktivnosti in povpraševanja po alternativnih ter adrenalinskih športih (Coakley, 2004).

Športni turizem kot oblika turizma v današnjem času omogoča številne razvojne priložnosti ter postaja vedno pomembnejši dejavnik oblikovanja turizma številnih turističnih destinacij (Standeven in De Knop, 1999, str. 12, glej sliko 9.1). V Nacionalnem programu športa v Republiki Sloveniji je športni turizem opredeljen kot "turizem za povpraševalce, ki imajo posebno zanimanje za turistične destinacije, kjer so lahko športno dejavni ali pa je šport zanje glavni motiv potovanja» (»Resolucija o Nacionalnem programu športa v Republiki Sloveniji 2014-2023", 2014, str. 48). Športni turizem je tudi gonilna sila za gospodarski razvoj urbanih območij, ki ob vzajemnem sodelovanju športnih in turističnih deležnikov vpliva tudi na trajnostni razvoj turističnih destinacij.

V zadnjih desetletjih je turistična dejavnost dosegla velik preskok $v$ zavedanju o razvoju športnega turizma. Spremembe in trendi preživljanja prostega časa turističnim destinacijam omogočajo oblikovanje kvalitetne ponudbe športnega turizma. Svetovne turistične destinacije zato razvijajo zanimive koncepte turističnih produktov, ki vsebujejo različne športne aktivnosti. Ti moderni koncepti destinacijam omogočajo, da odstopajo od svojih konkurentov in s tem povečujejo svojo konkurenčno prednost na mednarodnem trgu. Novi inovativni športnoturistični produkti privabljajo turiste, ki se srečujejo $\mathrm{z}$ naravo, spoznavajo druge ljudi in uživajo $\mathrm{v}$ bolj zdravih in za njih prilagojenih počitnicah.

Različne oblike športnega udejstvovanja sodobnim pomenijo (Weed in Bull, 2009; Hinch in Higham, 2001, str. 56; Higham in Hinch, 2009; Gibson, 2003, str. 355; Gibson idr., 1998, str. 49; Gammon in Kurtzman, 2002):

- turistom pomemben potovalni motiv, 
- ponudnikom turističnih proizvodov potrebo po povezovanju športa in turizma,

- lokalnemu prebivalstvu priložnosti vključevanja na področjih družbeno-kulturnega in ekonomskega udejstvovanja.

\section{Definicije in vrste športnega turizma}

Široko zasnovana definicija športnega turizma zajema potovanje oseb iz primarnega kraja bivanja z namenom sodelovanja $\mathrm{v}$ športni aktivnosti (rekreacijsko ali tekmovalno), obiska ali udeležbe na športni prireditvi (rekreativno ali profesionalno športno tekmovanje) in obiska športnoturistične atrakcije, ki predstavlja s športom povezano zapuščino (Gibson idr., 1998, str. 53). Številni avtorji, ki raziskujejo področje športa in turizma (Gibson, 2006; Weed, 2008; Hinch in Higham, 2001; Glyptis in Cooper, 1991; Kurtzman in Zauhar, 1995; Gammon in Robinson, 2003; Ritchie in Adair, 2004; Weed, 2009), se trudijo poiskati enotno definicijo športnega turizma. Berčič idr. (2010, str. 35) definicijo opredelijo $z$ vidika povezovanja športa in turizma, kjer sta »šport in turizem v svojem generičnem bistvu zasnovana na neekonomskih motivih, kjer udeleženci ob urejeni materialni osnovi predvsem trošijo svoja sredstva za zadovoljevanje zdravstvenih, prostočasnih, družbenih in kulturnih potreb«.

Športni turizem kot akademska disciplina se je v zadnjih dveh desetletjih močno razvil. Danes obstajajo številni učbeniki, organizirane akademske in profesionalne konference, univerzitetni programi dodiplomskega, podiplomskega in doktorskega študija športnega turizma. Poleg naštetega imamo bralci in raziskovalci tega področja danes na voljo številne znanstvene časopise, ki obravnajo tematike s področja športnega turizma. Najbolj prepoznaven in cenjen je Journal of Sport and Tourism, ki ga izdaja priznana založba Taylor \& Francis.

Začetki definiranja področja športnega turizma so bili najbolj zaznamovani med letoma 1993 in 2000. Avtorji, ki so ponudili osnove definiranja področja so predstavili poglede na to vrsto turizma z vidika politike, družbe in gospodarstva. Standeven in DeKnop (1999, str. 12), ki veljata za začetnika raziskovanja športnega turizma, to področje vidita kot različne oblike aktivne in pasivne vključenosti v športne aktivnosti izven domačega (delovnega) okolja, v katerih posameznik sodeluje naključno ali na organiziran način iz nekomercialnih ali poslovnih razlogov. 
H. Gibson idr. (1998, str. 49), ki so prav tako orali ledino raziskovanja področja, športni turizem delijo na tri vrste športnega turizma, povezanega $\mathrm{z}$ vedenjem ljudi:

- aktivni športni turizem (aktivna udeležba v športu),

- prireditveni športni turizem (spremljanje športnih prireditev),

- nostalgični športni turizem (obiski, namenjeni spoštovanju zapuščine športa).

Weed in Bull (2009, str. 123) športne turiste delita na pet različnih tipov športnega turizma:

- pasivni športni turizem (motiv potovanja in destinacije ni nujno odvisen od športa, ampak od drugih dejavnikov),

- aktivni športni turizem (motiv potovanja je pogojen z aktivno športno udeležbo posameznika, npr. smučanje, tenis in tek),

- športni turizem kot trening (priprave profesionalnih in amaterskih ekip in razni športni kampi za učenje športnih aktivnosti),

- elitni športni turizem (motiv potovanja je aktivna udeležba na golf tekmovanjih, pri jadranju ali udeležba elitnih športnih tekmovanj kot npr. Formula 1),

- prireditveni športni turizem (motiv je obisk športne prireditve lokalne ali globalne razsežnosti).

Weed in Bull (2009) za razliko od H. Gibson idr. (1998) kot potovalni motiv športnega turista opredelita povezovanje zgodovine športa in turizma. Poleg tega avtorja udeležence prireditvenega športnega turizma označita kot športne turiste, ki se ob spremljanju športne prireditve poistovetijo s tekmovalci (angl. vicarious' participation). Avtorja (Weed in Bull, 2009 v Weed, 2009, str. 618) še ugotavljata, da lahko na športni prireditvi poleg navijačev (pasivni udeleženci) sodelujejo športno aktivni turisti udeleženci (npr. rekreativni tekmovalci na organiziranem maratonu ali kolesarskem tekmovanju). Aktivni udeleženci športnih prireditev zaradi velikega števila organiziranih rekreativnih športnih prireditev postajajo pomemben segment raziskovanja športnoprireditvenega turizma.

Leta 2005 je Weed ponudil svoj malce kritičnejši pogled pri definiranju športnega turizma, ki je presegal samo opisovanje in razumevanje področja športnega turizma. Svoje raziskovanje področja je postavil v kontekst prepletanja treh različnih področij: aktivnosti, prostora in ljudi. 


\section{Slika 9.3}

Športni turizem kot prepletanje aktivnosti, ljudi in prostora (prirejeno po Weed, 2005, v Higham in Hinch, 2018)

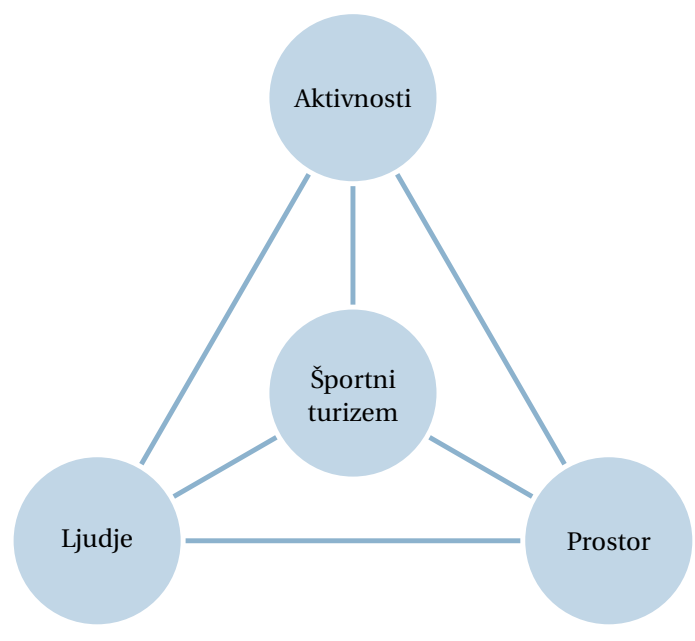

V svoji razširjeni definiciji športnega turizma Weed in Bull (2009) kasneje izpostavita, da je športni turizem družbeni, gospodarski in kulturni pojav, ki izhaja iz edinstvene interakcije dejavnosti, ljudi in kraja.

Gammon in Ramshaw (2012) športni turizem delita na dve vrsti:

- mehka definicija športnega turizma: športni turist potuje zaradi prostočasnih ali rekreativnih razlogov (npr. pohodništvo ali kajak);

- trda definicija športnega turizma: udeleženci športnih tekmovanj (npr. Svetovno prvenstvo v nogometu, Formula 1, olimpijske igre idr.).

Po mnenju avtorjev ima spekter dodatnih športnoturističnih proizvodov (športni muzeji, dvorane slavnih, podelitve priznanj, tematski dogodki za nekdanje ali aktivne športnike) prav tako velik potencial v športnem turizmu.

Športni turizem prav tako zajema profesionalni šport, ki obsega potovanja športnikov in njihovih spremljevalcev ter postaja pomemben segment poslovno-športnega turizma (Mihalič in Gartner, 2003). Za poslovni športni turizem $v$ obliki priprav profesionalnih športnikov sta predvsem potrebna ustrezna športna infrastruktura in znanje na področju vrhunskega športa.

Športni turizem je torej vrsta turizma, ki je primarno ali prevladujoče povezana s športom. Vključuje potovanja, kjer se posameznik začasno oddalji iz svojega običajnega okolja z motivom: 
Preglednica 9.1 Vrste športnega turizma in uporabniki

\begin{tabular}{|c|c|c|}
\hline Namen potovanja & Poslovni turisti & Prostočasni turisti \\
\hline $\begin{array}{l}\text { Potovanje zaradi športne } \\
\text { aktivnosti }\end{array}$ & $\begin{array}{l}\text { Športne priprave (vrhun- } \\
\text { ski športniki), športni } \\
\text { kampi (řportne šole, šole } \\
\text { v naravi) }\end{array}$ & $\begin{array}{l}\text { Zeleni športi (pohodni- } \\
\text { štvo, kolesarjenje, tek, ja- } \\
\text { hanje, golf, tenis, pleza- } \\
\text { nje); vodni športi (plava- } \\
\text { nje, navtika in jadranje, } \\
\text { rafting, kajak, kanu, ribo- } \\
\text { lov); zimski športi (smu- } \\
\text { čanje, tek na smučeh); } \\
\text { drugi športi (adrenalisnki } \\
\text { športi, podzemne dejav- } \\
\text { nosti, ples) }\end{array}$ \\
\hline $\begin{array}{l}\text { Potovanje zaradi obiska } \\
\text { špotne prireditve }\end{array}$ & $\begin{array}{l}\text { Športniki, spremljeval- } \\
\text { ci športnikov, mediji, so- } \\
\text { dniki, ostali predstavniki } \\
\text { športnih zvez }\end{array}$ & $\begin{array}{l}\text { Aktivna udeležba na tek- } \\
\text { movanjih (športniki); } \\
\text { obisk prireditve (gledalci, } \\
\text { navijači) }\end{array}$ \\
\hline $\begin{array}{l}\text { Potovanje zaradi obiska } \\
\text { športne zapuščine }\end{array}$ & $\begin{array}{l}\text { Športniki, mediji, ocenje- } \\
\text { valci, predstavniki špor- } \\
\text { tnih zvez }\end{array}$ & Športni navdušenci \\
\hline
\end{tabular}

Opombe Prirejeno po Uran Maravić idr. (2014).

- aktivne udeležbe v športu,

- gledanja oz. spremljanja športne prireditve ali aktivne udeležbe na športnem tekmovanju

- obiska športnoturističnih znamenitosti ali

- udeležbe športnih priprav in obiska športnih kampov.

Športni turist je:

- tisti obiskovalec, ki v destinaciji prespi vsaj eno noč in

- katerega primarni in/ali prevladujoči motiv prihoda na destinacijo je šport (športna aktivnost, ogled športne prireditve, ogled športnih znamenitosti, športne priprave in tekmovanja).

Športni turist je torej lahko oseba, katere motiv prihoda na destinacijo športnega turizma je vezan na poslovne ali prostočasne razloge. Klasifikacijo športnoturističnih proizvodov na podlagi teh opredelitev podajamo v preglednici 9.1.

Zaključimo lahko, da sta tako šport kot turizem kompleksna, vendar nepogrešljiva dejavnika moderne družbe. Zaradi tega je njuna smiselna povezava nujno potrebna, hiter razvoj športnega turizma pa je glede na potovalne trende nekaj povsem samoumevnega. 


\section{Športnoturistična doživetja v Sloveniji}

Turizem je v Sloveniji hitro rastoča panoga, ki letno v bruto domači proizvod prispeva skoraj 13-odstotni delež (Slovenska turistična organizacija, b.l.). Slovenija je podobno kot druge razvite svetovne turistične destinacije prepoznala moč in pomen športnega turizma. Šport in turizem sta ob sodelovanju dejavnika, ki pomembno vplivata na turistično ponudbo Slovenije. Turizem je povezovalna storitvena dejavnost in skupaj s športno ponudbo predstavlja motiv za prihod turistov z željo aktivnega preživljanja prostega časa, obiska športne prireditve, športnega treninga oz. športnih priprav in obiska znamenitosti, povezanih s športno nostalgijo.

Turističnopromocijski slogan "Zelena. Aktivna. Zdrava.«, ki ga je uvedla Slovenska turistična organizacija (sтo), nakazuje na pomembnost razvoja športnega turizma v Sloveniji. V novi Strategiji trajnostne rasti slovenskega turizma 2017-2021 (Ministrstvo za gospodarski razvoj in tehnologijo, 2017) športni turizem (celoletni produkt za športne ekipe na pripravah, športni dogodki in športna prvenstva evropskega ali svetovnega formata) predstavlja pomemben dejavnik za razvoj turizma v Sloveniji. V povezovanju z aktivnostmi na prostem (celoletni aktivni športi v naravi, kot so kolesarjenje, pohodništvo, vodni športi, zračni športi, smučanje) slovenski turizem tako domačim kot tujim turistom ponuja številne možnosti "petzvezdičnih" doživetij, povezanih s športom. Slovenija na področju zdraviliškega turizma (angl. wellness tourism) dobro izkorišča tudi naravne danosti termalne vode s produktom "zdravje in dobro počutje« (celoletni produkt, ki se osredotoča na zdravje, preventivo, "wellness", sprostitev in termalna vodna doživetja za obiskovalce vseh starosti). Skupek ponudbe različnih vsebin, povezanih s športom in dobrim počutjem, Slovenijo pozicionira kot državo, ki lahko turistom ponudi trendovske turistične produkte zdravega življenja, ki so podprti z znanjem s področja zdravstva in kineziologije (Ministrstvo za gospodarski razvoj in tehnologijo, 2017).

S celovito ponudbo se Slovenija uvršča med države, ki lahko turistu na področju športnega turizma ponudijo celovit produkt različnih vrst športnega turizma. Visoko kakovostna športna in ostala infrastruktura, podprta z namestitvenimi kapacitetami, predstavlja temelj za konkurenčnost ponudbe športnega turizma v Sloveniji. To športno turistično ponudbo vsako leto dopolnjujejo vrhunsko orga- 
nizirane športne prireditve (npr. Svetovni pokal v smučarskih skokih Planica, Ljubljanski maraton in različna evropska prvenstva v ekipnih športih), ki so organizirane v različnih destinacijah širom države (Slovenska turistična organizacija, b.l.). Tako kot druga področja razvoja turizma v Sloveniji so usmeritve na področju športnega turizma usmerjene v zagotavljanje kakovosti ponudbe. Slovenija se na področju turizma pozicionira kot "globalna zelena butična destinacija za zahtevnega obiskovalca, ki išče raznolika in aktivna doživetja, mir in osebne koristi«, zato tudi na področju športnega turizma razvija športnoturistične proizvode, ki zagotavljajo kakovost s poudarkom na vrhunski individualni izkušnji gosta (Slovenska turistična organizacija, b.l.).

\section{Globalni trendi na področju športnega turizma}

Šport in turizem postajata ena izmed novih oblik preživljanja prostega časa. Predvsem mlajše generacije danes preko novonastalih športnih disciplin odkrivajo nove oblike turizma, ki lahko v bodoče postanejo množični pojavi. Eno takih področij postaja področje ponudbe elektronskega športa (v nadaljevanju e-športa). Zgodnji začetki e-športa segajo v leto 1972, ko je bilo na Univerzi Stanford organizirano prvo e-športno tekmovanje v igranju videoigre $\mathrm{z}$ imenom Spacewar. Tekmovanje, imenovano Intergalactic Spacewar Olympics, so organizirali nekateri napredni študenti in danes velja za začetek e-športnih prireditev. Zmagovalec turnirja je prejel letno naročnino na revijo Rolling Stone. (Esports, b.l.). Če pogledamo zgodovino izraza e-šport, ugotovimo, da ta sega $v$ pozna devetdeseta leta, natančneje v leto 1999, in je tesno povezan z ustanovitvijo Združenja spletnih igralcev (angl. Online Gamers Assocciation) in prvih medijskih primerjav (Gestalt, 1999) med športom in e-športom (elektronskim športom). Danes se interakcije med uporabniki različnih videoiger (tudi športnih) odvijajo na glavnih virtualnih platformah, kot sta Twitch in YouTube Gaming. Uporabnikom omogočajo neposredno povezavo med igralci in ekipami in s tem močno vplivajo na razcvet industrije elektronskih vsebin videoiger. Najprepoznavnejše e-športne igre zadnjih 10 let, ki združujejo številne igralce na globalni ravni, so »League of Legends«, »Cs:GO«, »DOTA2« in »Overwatch«. Trenutno najprepoznavnejša e-športna igra pa je angl. »Fortnite«, ki je na trgu e-športne industrije prisotna od leta 2017 (Newzoo, 2018). Industrija videoiger, v katero spadajo tudi e-športne vsebine, je za 
uporabnike postala pomemben del sodobne potrošnje v virtualnem svetu. E-šport tako postaja hitro rastoči segment, ki vključuje številne interakcije med uporabniki, podjetji in različnimi deležniki, ki so zaznali priložnosti za povezovanje v virtualnem e-športnem okolju.

Področje e-športa je precej prepleteno, saj se vanj poleg uporabnikov elektronskih vsebin vedno bolj vključujejo tudi globalni sponzorji, mediji in vrhunske športne ekipe (nogometni, košarkarski in drugi športni klubi/organizacije). Statistični podatki (Soto Reyes, 2019) kažejo, da število uporabnikov e-športnih vsebin narašča za $9 \%$ letno. Po ocenah se bo število uporabnikov s 454 milijonov v letu 2019 do leta 2023 povečalo na 646 milijonov. Glede na podatek, da je bilo leta 2017 aktivnih uporabnikov 335 milijonov, gre skoraj za dvakratno povečanje do leta 2023 (Soto Reyes, 2019). Esports Ecosystem Report (Soto Reyes, 2019) za leto 2019 navaja podatek, da naj bi letni prihodki z naslova e-športa presegli milijardo ameriških dolarjev. Organizacija Newzoo (glede na podatke Statista) pa napoveduje, da bodo prihodki z naslova e-športa do leta 2020 dosegli zavidljivo številko 1,8 milijarde ameriških dolarjev, primarno z naslova medijskih pravic, prodaje blaga in storitev, sponzorstev in oglaševanja (Newzoo, 2018). Tri najmočnejše izvozne globalne trge e-športa (prihodki in občinstvo) predstavljajo regija Azija - Pacifik (angl. APAC), Severna Amerika in Evropa. V deležu to pomeni $85 \%$ celotnega trga e-športa (Soto Reyes, 2019).

Ko govorimo o e-športnem turizmu, mislimo na organizirana potovanja za ogled tekmovanj v e-športu. Gre za organizacijo velikih e-športnih turnirjev, ki v večnamenske športne dvorane po celem svetu privabijo veliko število ljudi. Ti novodobni e-športni navijači spremljajo e-šport zvezdnike pri igranju videošportnih vsebin. Tekmovanja v e-športnih igrah vabijo e-športne navdušence s celega sveta k spremljanju turnirjev v živo. Organizatorji tekmovanj imajo možnosti direktnih spletnih (angl. stream) prenosov tudi v gostinskih obratih (bari in restavracije), kar predstavlja dodatne priložnosti za promocijo in spremljanje e-športnih vsebin. Te vsebine danes že lahko spremljamo tudi preko globalnih televizijskih hiš s komentatorji in posebnimi strokovnjaki s področja e-športnih vsebin (npr. Sky Sports).

Zaradi generacijskih sprememb danes na področju organizacij športnih prireditev beležimo številne nove trende, ki kreirajo ponudbo področja e-športa in e-športnih prireditev. Če so predstavniki ge- 
neracije $X$ hodili na dejanske športne prireditve, danes predstavniki generacij $\mathrm{Y}$ in $\mathrm{Z}$ veliko več pozornosti namenijo e-športnim (angl. on-line) oblikam športnih tekmovanj. Predvsem generacije milenijcev so tiste, ki največ pripomorejo k vzponu in nenehni rasti ponudbe e-športnega turizma - to se vidi tudi $\mathrm{v}$ prihodih mednarodnih turistov na organizirane turnirje e-športnih dogodkov predvsem $\mathrm{v}$ azijskih državah, kjer so te vsebine najbolj razširjene in najpopularnejše.

Ponudniki e-športnih prireditev se danes vedno več povezujejo $s$ športnimi organizacijami (npr. s franšizami NBA, NFL, NHL). E-šport tako postaja resen igralec na trgu in sodelovanje s športnimi organizacijami (predvsem v ZDA), mediji in tehnološkimi podjetji postaja za slednje vedno zanimivejše. Velike športne franšize, ki jim sledijo njihovi navijači, se danes zavedajo prehoda na e-športne vsebine, zato se nenehno povezujejo $\mathrm{z}$ organizacijami s področja e-športnih vsebin - to predstavlja nove priložnosti za nove (drugačne) navijače, ki jih do sedaj niso mogli prepričati k obisku tradicionalnih športnih vsebin (fizični obisk). S ponudbo e-športnih vsebin se torej odpirajo nove možnosti promocije in povezovanja, ki vodijo h končnemu cilju - prodaji prilagojenih vsebin uporabnikom in s tem širitvi na e-trg poslovanja (Droesch, 2019).

Verjetno najzanimivejšo ponudba na področju e-športa danes predstavljajo organizirani turnirji igranja videoiger $\mathrm{z}$ visokimi nagradnimi skladi (tudi do 400.000 ameriških dolarjev). Ti pritegnejo zanimanje številnih obiskovalcev, ki spremljajo današnje novodobne globalne zvezde - mojstre igranja videoiger. Eden izmed glavnih organizatorjev e-športnih turnirjev je danes organizacija Turtle Entertainment, ki organizira številne e-športne turnirje (Katowice, POL, Frankfurt, NEM, Malaysia ...). Analize kažejo, da je prodaja vstopnic za turnirje podobna kot pri nekaterih globalnih športnih prireditvah - večja kot je pomembnost turnirja, hitreje e-športni navdušenci pograbijo vstopnice (Soto Reyes, 2019).

Ob hitrem vzponu e-športnih vsebin se na globalnem trgu vzporedno ponujajo priložnosti za številne destinacije, ki se usmerjajo $\mathrm{v}$ ponudbo e-športnih vsebin. Ena takšnih je kitajska destinacija Hangzhou, ki veliko vlaga v infrastrukturo (dvorane) za organizacijo turnirjev v igranju e-športa. Projekcije so, da bodo do leta 2022, ko bo Hangzhou gostil veliko športno tekmovanje (azijske igre), zgradili 14 novih dvoran, ki bodo tudi služile kot baza za 10.000 e-športnih igral- 
cev. Po nekaterih podatkih pa naj bi leta 2022 v času organizacije azijskih iger, e-športna tekmovanja prvič spremljali tudi kot športno disciplino, kjer se bodo tekmovalci borili za medalje (Fitch, 2018).

Hangzhou tako postaja prestolnica e-športnih vsebin s poudarkom na igranju videoiger. Nova infrastruktura bo zajemala e-športne tematske parke, e-šport hotele, e-športno akademijo in celo bolnišnico za zdravljenje e-športnikov (igralcev videoiger). Seveda vlaganja $v$ novo infrastrukturo in ponudbo e-športnih vsebin pomenijo več obiska mednarodnih turistov in navdušencev za ponudbo ešportnih vsebin. Južna Koreja, ki prav tako postaja ena izmed vodilnih destinacij e-športnega turizma, opaža probleme na področju jezikovnih ovir za mednarodne goste. $\mathrm{V}$ prihodnje bo potrebno poleg glavnega produkta ponudbe e-športnih vsebin in tekmovanj zagotoviti tudi ustrezne podporne produkte in s tem omogočiti možnost udeležbe globalnemu občinstvu. E-šport in e-športna tekmovanja so nova oblika ponudbe športnih vsebin, ki pritegnejo nove generacije uporabnikov. V te vsebine so danes vključeni predvsem tisti, ki jih klasična športnoprireditvena industrija s svojimi klasičnimi produkti ni nujno dosegla. To so novi uporabniki, ki jih bo potrebno analizirati in jim ponuditi vsebine preko modernih novih tehnologij ter jim zagotoviti tudi ustrezno oblikovano turistično izkušnjo.

\section{Zaključek}

Šport je danes prisoten v vseh porah družbe, pa naj gre za športno vzgojo (telovadbo), športne aktivnosti v naravi, športne prireditve ali pa vrhunski šport. Podobno velja za turizem, ki vključuje številne deležnike in mnogim omogoča priložnosti za povezovanje in predvsem poslovno sodelovanje. Ko združimo šport in turizem, dobimo vrsto turizma, ki ga danes imenujemo športni turizem. Ta vključuje širok obseg s športom povezanih aktivnosti v družbi. Tako je danes športni turizem več kot samo športna aktivnost v naravi v času dopusta. Pomemben delež športnega turizma predstavljajo tudi športne prireditve (velika globalna športna tekmovanja kot tudi manjše lokalne športne prireditve), športna nostalgija (zgodovina športa, ki jo lahko danes ponudimo kot turistično doživetje) in športne priprave tako vrhunskih športnikov kot tudi otrok in mladine. Seveda je za aktivnejše posameznike športni turizem postal del njihovega vsakdanjika.

Šport ljudem že stoletja predstavlja glavni motiv za potovanje. 
Športni turisti zaradi njega potujejo na izbrano destinacijo njihovega dopusta. Potovanja so pogosto povezana z obiskom športne prireditve (npr. olimpijskih iger ali Svetovnega prvenstva v nogometu) ali pa celo močno povezana $\mathrm{z}$ neposredno športno aktivnostjo (aktivni udeleženec maratona ali pa nastop na prestižnem triatlonskem tekmovanju Ironman). Poslovni del športnega turizma predstavljajo športne priprave vrhunskih športnikov (priprave v pripravljalnih športnih kampih pred sezono) ali pa številni športni kampi za mladino in otroke, ki se poleg športnih aktivnosti in treninga tudi medsebojno družijo in tako kvalitetno preživljajo svoj prosti čas (npr. Hokejska akademija Anžeta Kopitarja in Tomaža Razingerja).

V Sloveniji lahko na področju športnega turizma ponudimo številne športnoturistične produkte. Naša največja dodana vrednost so vsekakor neokrnjena narava in $\mathrm{z}$ njo povezane športne aktivnosti $\mathrm{v}$ naravi (npr. »outdoor« aktivnosti). Izkoriščanje naravnih virov predstavlja naš največji adut, ko vabimo športne turiste s celega sveta. Imamo pa v Sloveniji poleg neokrnjene narave še mnoge druge zelo kvalitetne produkte s področja športnega turizma. Tukaj moramo izpostaviti vrhunsko organizacijo velikih športnih prireditev (npr. EuroBasket 2013, Svetovni pokal v smučarskih skokih Planica, tekmovanji v alpskem smučanju Zlata lisica in Vitranc). To ponudbo zaokrožujejo tudi nekatere druge svetovno znane vrhunsko organizirane športne prireditve, ki jih organizirajo posamezniki, podjetja oz. športna društva (npr. I feel Slovenia Ironman 70.3 slovenska Istra, Ljubljanski maraton, Soča Outdoor Festival ...). Poleg tega se v zadnjem obdobju z organizacijo zelo atraktivnih športnih prireditev (npr. Odbojka na Ljubljanici, Red Bull Goni Pony, Spartan Race Slovenia ...) ter s pomočjo modernih marketinških prijemov kot država postavljamo na turistični zemljevid atraktivnih športnih prireditev.

Področje športnega turizma je v Sloveniji krovno povezano s sloganom Slovenske turistične organizacije "Zelena. Aktivna. Zdrava.", ki omogoča, da to področje razvijamo na ustrezen način. Seveda so smernice dodatno izpostavljene v Strategiji trajnostne rasti slovenskega turizma 2017-2021 (Ministrstvo za gospodarski razvoj in tehnologijo, 2017). Krovni turistični dokument s podlago trajnostnega razvoja turizma tako deležnikom s področja športnega turizma omogoča, da sledijo zelenemu, zdravemu in aktivnemu razvoju športnega turizma v Sloveniji. Te smernice so opredeljene kot nosilni in sekundarni podporni produkti za vsako izmed izpostavljenih makro- 
regij (alpska, termalna panonska, osrednjeslovenska in Ljubljana ter mediteranska) v Sloveniji in so podlaga za razvoj ter oblikovanje butičnih športnoturističnih produktov za zahtevnega gosta. Samo z vrhunskimi trajnostno usmerjenimi športnoturističnimi produkti bomo v prihodnje lahko sledili strateškemu razvoju turizma v Sloveniji in s tem ustvarjali večjo dodano vrednost našega turizma (Ministrstvo za gospodarski razvoj in tehnologijo Republike Slovenije, 2017).

$\mathrm{V}$ zaključku je seveda potrebno izpostaviti tudi nova področja športnega turizma, ki so usmerjena predvsem v e-športne oblike ponudbe področja. Pri pripravi prihodnjih strateških turističnih dokumentov bo potreben razmislek o vključevanju e-športnih vsebin. Bodoče generacije turistov bodo iskale tudi te športnoturistične produkte in tukaj moramo poskrbeti za njihov razvoj in implementacijo v obstoječo ponudbo športnega turizma države.

\section{Literatura}

Bartoluci, M., in Čavlek, N. (2007). Turizam i sport-razvojni aspekat. Školska knjiga.

Berčič, H., Sila, B., Slak Valek, N., in Pintar, D. (2010). Šport v turizmu. Fakulteta za šport.

Coakley, J. (2008). Sport in society: Issues and controversies. McGraw-Hill.

Davies, J., in Williment, J. (2008). Sport tourism - Grey sport tourists, all black and red experiences. Journal of Sport \& Tourism, 13(3), 221-242.

Droesch, B. (2019, 19. marec). How the $\mathrm{NBA}$ is using esports to grow its audience. Emarketer. https://www.emarketer.com/content/how-thenba-is-using-esports-to-grow-its-audience

Resolucija o Nacionalnem programu športa v Republiki Sloveniji 20142023 (RеN Pš14-23). (2014). Uradni list Republike Slovenije, (26). https: //www.uradni-list.si/1/objava.jsp?sop=2000-01-1065

Edwards, H. (1973). Sociology of sport. Dorsey Press.

Esports. (B. 1.). History of esports. https:// esportsforgamers.weebly.com/ history-of-esports.html

Eurostat. (2018). Sport statistics: 2018 edition. Publication Office of the European Union.

Fitch, A. (2018, 21. november). Hangzhou opens its own esport town. Esports Insider. https://esportsinsider.com/2018/11/hangzhou -esports-town/

Fourie, J., in Santana-Gallego, M. (2011). The impact of mega-sport events on tourist arrivals. Tourism Management, 32(6), 1364-1370.

Gammon, S., in Kurtzman, J. (2002). Sport tourism: Principles and practice. Leisure Studies Association Publications. 
Gammon, S., in Robinson, T. (2003). Sport and tourism: A conceptual framework. Journal of Sport \& Tourism, 8(1), 21-26.

Gammon, S., in Ramshaw, G. (2012). Nostalgia and sport. V A. Fyall in B. Garrod (ur.), Contemporary cases in sport (str. 201-220). Goodfellow Publishers.

Gestalt. (1999, 23. december). The oGA: What the hell is it? Eurogamer. http://www.eurogamer.net/article.php?article_id=105

Gibson, H. J. (2003). Sport tourism. V J. B. Parks in J. Quarterman (ur.), Contemporary sport management (2. izd., str. 337-361). Human Kinetics Publishers.

Gibson, H. (2006). Sport tourism: Concepts and theories. Routledge.

Gibson, H., Attle, S., in Yiannakis, A. (1998). Segmentation the active sport tourist market: A life span prospective. Journal of Vocation Marketing, 4(1), 52-64.

Glyptis, S. A., in Cooper, C. (1991). Sport and tourism. Progress in Tourism, Recreation and Hospitality Management, 3, 165-183.

Higham, J., in Hinch, T. (2009). Sport and tourism. Routledge.

Higham, J., in Hinch, T. (2018). Sport tourism development. Channel View Publications.

Hinch, T., in Higham, J. (2001). Sport tourism: A framework for research. International Journal of Tourism Research, 3(1), 45-58.

Hinch, T., in Higham, J. (2004). Sport tourism development. Channel View Publications.

Hudson, S. (2003). Sport and adventure tourism. Haworth.

Kurtzman, J., in Zauhar, J. (1995). Tourism Sport International Council. Annals of Tourism Research, 22(3), 707-708.

Lesjak, M. (2018). Velike športne prireditve in turizem: teoretični in raziskovalni vidik merjenja vplivov velike športne prireditve. Založba Univerze na Primorskem.

Mihalič, T., in Gartner, W. (2003). How can sport activities contribute to tourism growth? Tourism Review, 58(4), 35-36.

Ministrstvo za gospodarski razvoj in tehnologijo. (2017). Strategija trajnostne rasti slovenskega turizma 2017-2021 [brošura]. https://www .slovenia.info/uploads/dokumenti/kljuni_dokumenti/strategija _turizem_koncno_9.10.2017.pdf

Newzoo. (2018). Free 2018 global esports market report [brošura]. https: //resources.newzoo.com/hubfs/Reports/Newzoo_2018_Global _Esports_Market_Report_Excerpt.pdf?

Ritchie, B. W., in Adair, D. (2004). Sport tourism: Interrelationships, impacts and issues. Channel View Publications.

Slak Valek, N. (2008). Primernost turistične ponudbe destinacije za povpraševanje športnoaktivnega turista - primer Slovenije [neobjavljena doktorska disertacija]. Univerza v Ljubljani. 
Soto Reyes, M. (2019, 18. december). Esports Ecosystem Report 2020: The key industry players and trends growing the esports market which is on track to surpass \$1.5B by 2023. Business Insider. https://www .businessinsider.com/esports-ecosystem-market-report

Standeven, J., in De Knop, P. (1999). Sport tourism. Human Kinetics Publishers.

Slovenska turistična organizacija. (B.1.). Turistični produkti. https:// www.slovenia.info/sl/poslovne-strani/razvoj-in-inovativnost/ turisticni-produkti

World Tourism Organization. (2002). Sport and tourism: Introductory report. https://www.e-unwto.org/doi/pdf/10.18111/9789284404179

Uran Maravić, M., Bednarik, J., Pišot, R., Sedmak, M., Lesjak, M., in Rameša, M. (2014). Analiza športnega turizma v Sloveniji [poročilo]. Spirit Slovenija.

Weed, M. E. (2005). Research synthesis in sport management: Dealing with »chaos in the brickyard «. European Sport Management Quarterly, 5(1), 77-90.

Weed, M. E. (2008). Sport \& tourism: A reader. Routledge.

Weed, M. E. (2009). Progress in sports tourism research? A meta-review and exploration of futures. Tourism Management, 30(5), 615-628.

Weed, M. E., in Bull, C. J. (2009). Sports tourism: Participants, policy \& providers (2. izd.). Elsevier. 